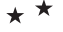

$\star$ Polityki Europejskie.

$\star$ Finanse i Marketing

$\star \star \star 16(65) 2016$

Wioletta Wereda

University of Natural Sciences and Humanities in Siedlce

Joanna A. Jończyk

Bialystok University of Technology

\title{
THE ROLE OF CUSTOMER SATISFACTION IN THE MODERN MARKETING ON THE EXAMPLE OF THE MARKET OF DENTAL SERVICES
}

\section{Rola satysfakcji klienta we współczesnym marketingu na przykładzie rynku usług stomatologicznych}

The awareness of a change to the health care prompts medical entities to continuously adapt to the expectations of beneficiaries and to improve the quality of services offered. This would not be possible without the continuous monitoring of the level of satisfaction of patients and analysis of the factors influencing their satisfaction. Patient satisfaction has become one of the main tools for shaping the quality of health care, and thus guarantee of the success of the organization in the market of dental services. The purpose of this paper is to present at the theoretical and practical level the role of consumer satisfaction in the market of medical services on the example of the market of dental services. The main methods used in the article was the verification of literature and primary sources obtained from the surveyed facilities, as well as the analysis of the results of the survey conducted among patients from Bialystok and its surroundings.

Key words: customer satisfaction, medical facility, dental services, contemporary marketing

\section{Introduction}

Systemic transformation in health care and the formation of a free market of medical services has forced medical entities to a broader look at the quality of their services ${ }^{1}$. The market of health services became like a competitive market, where there is competition between service providers and this is particularly evident in the field of dental services. Development of competition in this area caused a change in the position and role of the patient, who as conscious consumer is shaping the modern market of medical services by giving opinions about the dental facility and a selection of services best suited to the needs.

The quality of provided medical services is a key factor for increasing the competitiveness of the service providers. The dentist, who wants to provide patient services at the highest level must act in accordance with the principles of marketing.

${ }^{1}$ J. Jończyk J., Ocena satysfakcji pacjenta $w$ kontekście jakości opieki zdrowotnej, Prace Naukowe Uniwersytetu Ekonomicznego we Wrocławiu 151/2011, s.301-310. 
Lack of due attention to the specific needs of the patient carries the risk of losing a customer and a real danger of losing the reputation of the institution in the market of dental services ${ }^{2}$. The aim of this study was to identify factors of satisfaction of dental beneficiaries and determine the correlation between patient satisfaction and quality of dental services provided by the dental companies ${ }^{3}$ in Podlasie Region. Based on the purpose of the research problem the following research questions were posed:

1. What are the factors of patient satisfaction in case of dental services?

2. What factors of satisfaction are most important and which are least important from the point of view of the patient of the dental office?

3. How patient satisfaction reflected in the quality of dental services?

\section{Modern marketing and the quality of medical services}

Modern marketing is nothing but an evolution of traditional marketing towards a new generation of value. In the case of technological progress it can be identified at present era as Marketing 4.0, which creates a modern Client 3.0. In the new marketing concepts special importance is attached to creating relationships with customers with greater emphasis on their knowledge and ensure their satisfaction. Marketing has undergone a transformation from products to consumers and further stakeholders. The new Marketing 4.0 concept analysis of the human is carried out in four dimensions: mind, heart, spirituality and relationships and interactions, and therefore customer satisfaction especially in the sphere of services is so important in today's market ${ }^{4}$.

The supreme value, and also the destination of medical activity is health. Health is a specific value for a particular ethical dimension, not subject to valuation because it is a subjective state of the person directly concerned. The World Health Organization defines health as "the fullness of complete physical, mental and social well being and not merely the absence of disease or infirmity" ${ }^{15}$. In terms of economic health is "a special economic good, which is of significant value to the patient, resulting from both its direct and indirect impact achieved by the patient's level of satisfaction, and thus the value of the utility function." It is understood, therefore, that the main purpose of every individual is life in good health, which for most people is achievable only in situations where permanent, unrestricted access to the medical services of the highest quality is available.

Therapeutic activity consists in providing health services, as well as health promotion or carrying out teaching and research by specialized bodies, ie.$:$ medical entities within the meaning of the Act on medical activity ${ }^{6}$, including businesses in all

\footnotetext{
${ }^{2}$ B. Małecka, J. T. Marcinkowski, Satysfakcja pacjenta czynnikiem ksztaltujacym współczesny rynek ustug medycznych, „Problemy Higieny i Epidemiologii” 2007, nr 88, s. 17.

${ }^{3}$ Zgodnie z definicją zawartą w art. 2 ust. 1 pkt 8 ustawy z dnia 15 kwietnia 2011 r. o działalności leczniczej (Dz. U. z 2013 r. poz. 217) przedsiębiorstwo podmiotu leczniczego to zespół składników majątkowych, za pomocą którego podmiot leczniczy wykonuje określony rodzaj działalności leczniczej.

${ }^{4}$ Szerzej M. Adamowicz, Refleksje nad rozwojem i istota marketingu [w:] K. Pieniak-Lendzion, T. Nowogródzka, Wspótczesny marketing i logistyka-globalne wyzwania, Wydawnictwa UPH, Siedlce 2014, pp. $13-20$.

${ }^{5}$ Z. Zielińska (i in.), Potrzeby i popyt na uslugi medyczne, Materiały Konferencyjne, IRWiK, Warszawa 2000, s. 6 [za:] K. Krot, Jakość i marketing ustug medycznych, Wolters Kluwer Polska, Warszawa 2008, s. 12.

${ }^{6}$ Ustawa z dnia 15 kwietnia 2011 r. o działalności leczniczej (Dz. U. z 2013 r. poz. 217, z późn. zm.), art. 2 ust. 1 pkt 5.
} 
forms provided for the establishment, as well as doctors, nurses and midwives working in an individual or group specialized professional practice. Thus the circle of entities operating in the field of dentistry is narrowed down to a group of professionals with legitimacy and professional qualifications to provide health services. Medical services (including dental services) are made up of many elements, which can be divided into two basic groups:

- tangible factors (eg. the items purchased by the patient-client, items whose statute changes due to the resulting service; positions located on the periphery of the package of services - eg. Medical records, items, without which the service could not take place and the items that are part of the process - eg. technology),

- intangible factors (eg. a personal contact the service, the atmosphere of the environment in which the services are provided, sensations felt by the patient) ${ }^{7}$.

Regardless of the type of services that the organization provides, it must realize that part of the package of services offered includes both types of elements. As pointed out by A. Bukowska-Piestrzyńska, wanting to tangible and intangible factors form a coherent set of instruments having impact on the patient, it is necessary to determine the aim which institution has to achieve and select them in such a way that they can be adopted to achieve $\mathrm{it}^{8}$.

The literature points to the differences in quality of medical services depending on the subject, which is interested in quality and the context in which we talk about health care services. According to the provider quality is appropriate, consistent with current medical knowledge, the process of healing. From the point of view of the patient quality is determined by the availability of services, adequate information and health education, good communication with staff, coordination and continuity of the process of treatment and satisfaction with the care received. Value for the payer is associated with efficiency and effectiveness of health care, and also with achieving the desired results while minimizing medical cost ${ }^{9}$. Services specific to the area of health care can be determined by using three dimensions, such as the potential (the willingness and ability of service providers to take action for a customer), process (a sequence of episodes related to the course of treatment) and the result (result made by service) ${ }^{10}$.

Health care facilities offer services to patients consisting of two dimensions: technical and functional. Quality of service perceived by the patient is the result of comparison the quality expected - shaped by the so-called market communication (promotion), image service, customer reviews and buyer's needs - quality experienced so in technical and functional aspect (Table 1).

Technical quality includes all the elements that affect the result of operational processes, eg. medical equipment, equipment, knowledge and professional skills of employees used medical technologies, procedures and instructions used or accepted

\footnotetext{
${ }^{7}$ M. Dobska, P. Dobski, Marketing ustug medycznych, Wydawnictwo Infor, Warszawa 1999, s. 200-201.

${ }^{8}$ A. Bukowska-Piestrzyńska, Marketing ustug zdrowotnych - od budowania wizerunku placówki do zadowolenia klienta, CeDeWu, Warszawa 2007, s.. 13.

${ }^{9}$ K. Czarnecka, B. Różański, Jakość ustug a polityka samorzqdu lokalnego, „Służba Zdrowia” 1999, nr 3940, s. 9-10.

${ }^{10}$ A. Czerw (red.) Marketing w ochronie zdrowia, Difin, Warszawa 2010, s. 14.
} 
standards. Functional quality, however, is determined by the size of the contact between the provider and the recipient ${ }^{11}$.

Table 1. Factors of quality medical services

\begin{tabular}{|c|c|c|c|}
\hline $\begin{array}{l}\text { DIMENSIONS } \\
\text { OF QUALITY }\end{array}$ & $\begin{array}{l}\text { Features of potential } \\
\text { (expected value) }\end{array}$ & $\begin{array}{l}\text { Features of the process } \\
\text { (quality of experience } \\
\text { being) }\end{array}$ & $\begin{array}{l}\text { Features of a result } \\
\text { (received quality) }\end{array}$ \\
\hline $\begin{array}{l}\text { Technical } \\
\text { dimension } \\
\text { (internal) }\end{array}$ & $\begin{array}{l}\text { - } \quad \text { buildings and } \\
\text { interiors } \\
\text { - } \quad \text { technical equipment } \\
\text { (hardware, equipment) } \\
\text { - quality certifications } \\
\text { - information system }\end{array}$ & $\begin{array}{l}\text { - } \text { medical records } \\
\text { - } \text { competence of } \\
\text { personnel } \\
\text { - accuracy of diagnosis } \\
\text { - the duration of } \\
\text { treatment } \\
\text { - management }\end{array}$ & $\begin{array}{l}\text { - } \text { rate of return } \\
\text { recovery } \\
\text { - follow-up care } \\
\text { - treatment in case of } \\
\text { complaints }\end{array}$ \\
\hline $\begin{array}{l}\text { Functional } \\
\text { dimension }\end{array}$ & $\begin{array}{l}\text { Expectations formed by: } \\
\text { - facility image } \\
\text { - } \text { recommendations } \\
\text { - } \text { honors and awards } \\
\text { - } \text { price of the service } \\
\text { - previous experience } \\
\text { - needs and } \\
\text { demographic } \\
\text { characteristics of the } \\
\text { patient } \\
\text { educational programs }\end{array}$ & $\begin{array}{l}\text { - } \text { the relationship } \\
\text { between staff and } \\
\text { patients } \\
\text { - } \text { the relationship } \\
\text { between } \\
\text { staff establishments } \\
\text { - culture and } \\
\text { performance } \\
\text { support } \\
\text { - waiting time } \\
\text { the provision of } \\
\text { - atmosphere } \\
\text { at the facility } \\
\text { - way of non-medical } \\
\text { services } \\
\text { - additional services }\end{array}$ & $\begin{array}{l}\text { - } \text { recovery time } \\
\text { - consequences of } \\
\text { disease } \\
\text { - explanation of } \\
\text { actions } \\
\text { after discharge from } \\
\text { the hospital } \\
\text { - further maintaining } \\
\text { the relationship with } \\
\text { the patient }\end{array}$ \\
\hline
\end{tabular}

Source: K. Krot, quality and marketing of medical services, Wolters Kluwer Poland, and Warsaw 2008, p. 40.

Provision of health thus meet patients' expectations for quality, if you will take into account both of the dimensions of quality: technical (professionalism) and functional (professional relationships) ${ }^{12}$. The difference between the expected and the service actually received is subjective to every buyer service. In connection with the individualization of the perception of the quality of medical services is particularly important to the concept of "perceived quality of service" by the patient ${ }^{13}$. Selected

${ }^{11}$ A. Czerw, U. Religioni, Systemy oceny jakości w ochronie zdrowia, „Problemy Zarządzania” 2012, nr 2 (37), s. 197.

${ }^{12}$ A. Czerw, U. Religioni, op. cit., s. 198.

${ }^{13}$ A. Bukowska-Piestrzyńska, op. cit., s. 51-52. 
criteria perception of quality of service by the customer of dental practice are presented in Table 2.

Table 2. Criteria for the perception of service quality by the patient

\begin{tabular}{|c|c|c|}
\hline Criterion & Definition & Examples of questions \\
\hline CREDIBILITY & $\begin{array}{l}\text { honesty of the service provider, } \\
\text { trust }\end{array}$ & Is the dentist enjoys a good reputation? \\
\hline COMPETENCE & $\begin{array}{l}\text { formal qualifications and the } \\
\text { necessary knowledge }\end{array}$ & $\begin{array}{l}\text { Is selected orthodontist has } \\
\text { second degree specialization? }\end{array}$ \\
\hline COMMUNICATION & $\begin{array}{l}\text { listening to the voices of } \\
\text { customers, information in plain } \\
\text { language }\end{array}$ & $\begin{array}{l}\text { Is the dentist will be able to } \\
\text { explain to my } 6 \text {-year old child to the } \\
\text { process of treatment? }\end{array}$ \\
\hline $\begin{array}{l}\text { UNDERSTANDING THE } \\
\text { CUSTOMER }\end{array}$ & $\begin{array}{l}\text { subtracting the effort to know } \\
\text { clients } \\
\text { and their needs }\end{array}$ & $\begin{array}{l}\text { Will I be recognizable as a regular } \\
\text { patient? }\end{array}$ \\
\hline $\begin{array}{l}\text { ELEMENTS OF } \\
\text { MATERIAL }\end{array}$ & $\begin{array}{l}\text { the appearance of personnel, } \\
\text { facilities, equipment }\end{array}$ & $\begin{array}{l}\text { Do you have a camera inside the } \\
\text { cabinet - mouth? }\end{array}$ \\
\hline SECURITY & $\begin{array}{l}\text { freedom from doubt, risks, } \\
\text { hazards }\end{array}$ & Does the dentist use disposable gloves? \\
\hline RESPONSE & providing patients with fast food & $\begin{array}{l}\text { Will I be admitted with acute toothache } \\
\text { without saving? }\end{array}$ \\
\hline $\begin{array}{l}\text { SOLIDITY } \\
\text { / RELIABILITY }\end{array}$ & $\begin{array}{l}\text { accurate and reliable way } \\
\text { the service }\end{array}$ & $\begin{array}{l}\text { Is restoration will } \\
\text { offered to meet the characteristics? }\end{array}$ \\
\hline KINDNESS & respect, friendliness & $\begin{array}{l}\text { Is the receptionist will be nice when } \\
\text { I'll call you cancel a visit? }\end{array}$ \\
\hline ACCESS & affordability, ease of contact & $\begin{array}{l}\text { Is it possible to register for a specific } \\
\text { hour? }\end{array}$ \\
\hline
\end{tabular}

Source: Worm A. (ed.), Marketing in health care, Difin, Warsaw 2010, p. 22.

\section{Satisfaction of the consumer (patient) - the essence, models and measurement}

The patient as an external customer of a medical facility, is the most important element of the structure of the organization, which should be subordinated to all its activities. No therapeutic entity is able to achieve a high quality of health services without understanding and meeting the needs and expectations of the patient. Patient satisfaction with the service received should be the main objective of the actions taken by the provider in the field of quality management. 
The patient is any person using medical services, regardless of whether the person is sick or healthy ${ }^{14}$. The patient is entitled to certain, protected rights, which must be taken into account by the provider, in particular: the right to information, the right to consent to treatment, the right to privacy and dignity, the right to care and treatment.

Customer satisfaction is variously presented in the literature for example P. Kotler defines satisfaction as the "state felt by the body and connected with a comparison of perceived characteristics of the product and the expectations of individuals regarding these characteristics"15.

According to K. Mazurek-Łopacińska satisfaction is the "emotional response to the comparative processes started by the client, consisting of the combination of their experiences and feelings after consumption of a product or service with expectations, individual standards or specific evaluation pattern"16.

The complete definition of consumer satisfaction formulated R. B. Woodruff and S. F. Gardial, describing it as a positive or negative feeling a client in relation to the value received as a result of use of a particular product offered in a given situation. This feeling may be a direct reaction to the use of the product or complete response to a series of situations experienced ${ }^{17}$.

Among the steps leading to the achievement of satisfaction stand out:

- fulfillment - consisting in the offering by the company what the buyer needs

- value - meaning the fulfillment of the expectations of the buyer with regard to price,

- convenience - consisting of the easy availability of the product,

- confidence - the confidence of the buyer as to the fact that the product is trustworthy,

- $\quad$ achieving customer satisfaction ${ }^{18}$.

The level of customer satisfaction thus depends on the actual characteristics of the product or service, the individual characteristics of the buyer and its requirements for the product (service), communication policy pursued by the company and previous experience of the consumer. These factors affect the perception of the product or service by the purchaser and the shape of its expectations, and that as a result determine the level of satisfaction ${ }^{19}$.

Dental customer satisfaction from the received medical service shall be treated as the result of a psychological process, during which the patient compares the perceived

\footnotetext{
${ }^{14}$ K. Opolski, G. Dykowska, M. Możdżonek, Zarzadzanie przez jakość w ustugach zdrowotnych. Teoria $i$ praktyka, CeDeWu, Warszawa 2010, s. 58.

15 Cyt. za: L. Nieżurawski, B. Pawłowska, J. Witkowska, Satysfakcja klienta. Strategia - Pomiar Zarzqdzanie. Koncepcja wewnętrznego urynkowienia współczesnej organizacji, Wydawnictwo Naukowe Uniwersytetu Mikołaja Kopernika, Toruń 2010, s. 51-52.

${ }^{16}$ K. Mazurek-Łopacińska, Zachowania nabywców i ich konsekwencje marketingowe, PWE, Warszawa 2003, s. 305 .

${ }^{17}$ P. Nowicki, T. Sikora, Czynniki kształtujące satysfakcję klienta oraz korzyści z pomiaru satysfakcji klienta w procesie doskonalenia jakości [w:] Sikora T. (red.) Zarzadzanie Jakościa - Doskonalenie Organizacji, Wydawnictwo Uniwersytetu Ekonomicznego w Krakowie, Kraków 2010, s. 204-205.

${ }_{18}$ A. Iwanicka, Satysfakcja $i$ jej rola $w$ aktywności rynkowej nabywcy finalnego, „Zeszyty Naukowe Politechniki Rzeszowskiej” 2009, nr 260, s. 57.

${ }^{19}$ K. Mazurek-Łopacińska, op. cit., s. 308.
} 
level of business (quality of the existing business) with known standards of dental services, which generally coincide with expectations (expected quality) $)^{20}$.

The criteria, which may affect the sense of patient satisfaction with dental treatment include: patient age and sex, economic situation, the competence of the doctor providing the benefits, the course of communication between doctor and patient, the financial aspect related to the type of payer services (private treatment or treatment within social security), or the previous experience of the patient associated with a fear of visiting the dentist ${ }^{21}$.

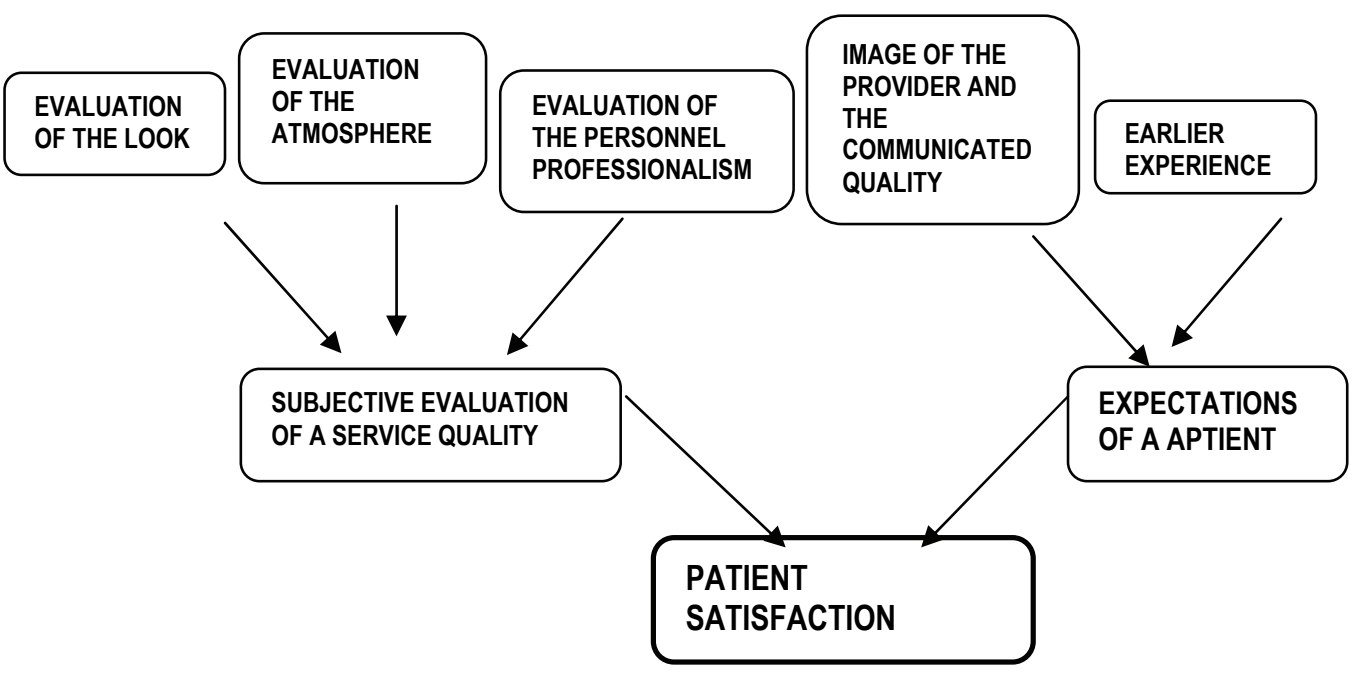

Figure 1. Elements which create patient satisfaction

Source: A. Bukowska-Piestrzyńska, Marketing usług zdrowotnych - od budowania wizerunku placówki do zadowolenia klienta, CeDeWu, Warszawa 2007, p. 70.

In studies on issues of patient satisfaction with the dental services the following factors are listed that affect patient satisfaction:

- accessibility to dental services (working time and location of dental surgery)

- exterior and interior looks of spaces in dental facility,

- range of services offered (multidisciplinary services)

- qualified doctors, staff competence,

- office equipment in medical equipment and devices,

- use of available information systems (website facility, keeping the customer database using the computer program)

- psychological conditions dental services - interpersonal contacts,

- standards of customer service and the atmosphere prevailing in the institution,

\footnotetext{
${ }^{20}$ L. Nieżurawski, B. Pawłowska, J. Witkowska, op. cit., s. 51.

${ }^{21}$ S. Makacewicz (i in.), Satysfakcja pacjenta z modelu kompleksowej opieki stomatologicznej, „Dental and Medical Problems" 2006, nr 43, s. 410.
} 
- financial issues related to the settlement for the service (eg. a free consultation and inspection of the oral cavity, various forms of rebates or discounts, the possibility of paying by credit card) ${ }^{22}$.

In the literature, there are several models to explain the formation of the client a sense of satisfaction or lack of it in a particular situation. Among them are:

- emotional model,

- model based on the theory of justice of exchange,

- model of the expected non-compliance,

- model of service quality,

- Kano model,

- concept formation of satisfaction based on the PROSAT model,

- model of the global customer satisfaction.

Both in practice and theory of the subject, there are many methods of measuring customer satisfaction. In order to obtain the most accurate and reliable measurements, it appears advisable to use several methods mutually complementary. During the study one should identify what factors are most important to customers when making choices and how they affect the behavior of buyers. Reliable measurement of satisfaction should specify: customer priorities, tolerance clients regarding the level of quality of service, the quality of the organization, the quality of the organization compared with the priorities of customers and the priorities of the competition, as well as priorities for improvement that allow the implementation of measures to raise the level of customer satisfaction ${ }^{23}$.

There are direct and indirect methods of testing the degree of customer satisfaction. Customer satisfaction surveys are studies of individual, which should be tailored to the specific problem of research, services or industry. For direct methods, which can be transposed to the health care system, include, among others ${ }^{24}$ :

- system of complaints and suggestions,

- focused newsgroups and user groups,

- personal or telephone interviews with customers,

- analysis of losing customers,

- analysis of customer loyalty,

- examination of the quality of employees,

- surveys of customers.

Other test methods for patient satisfaction in a direct way, extracted in the literature are: Blueprinting, Storybording, QFD - Quality Function Deployment, CSR - Customer Satisfaction Research, CRM systems (Customer Relationship Management) ${ }^{25}$, TRI*M method, analysis of the validity determinant or Six Sigma.

In this article it was used the surveys of customers. This method are seasonal, based on a questionnaire through which company asks respondents the two types of scaled questions concerning the same features offered. This method allows for quantitative and qualitative data, and the results reflect customer feedback on various aspects of the

\footnotetext{
${ }^{22}$ J. Szymańska (i in.), Satysfakcja pacjenta z ustug świadczonych w gabinecie stomatologicznym, „Zdrowie Publiczne" 2008, nr 118, s. 480.

${ }^{23}$ Ibidem, s. 70.

${ }^{24}$ Ibidem, s. 74-103.

${ }^{25}$ More in W. Wereda, Zarzqdzanie relacjami z klientem (CRM) a postępowanie nabywców na rynku ustug, Difin, Warszwa 2009.
} 
functioning of the organization. By carrying out a survey the company can assess the degree of customer satisfaction due to data attributes, as well as the degree of fulfillment of the criteria expected by customers.

\section{Customer satisfaction survey of dental services in Podlaskie Voivodship - the results of own study}

The primary determinant of the success of the organization in the market of medical services is the satisfaction of its customers received. Actions taken by medical entities, aimed at increasing the satisfaction of beneficiaries of medical services include research on patient satisfaction. They create the possibility to check what patients think about the quality of their services, as well as allow you to specify the deficiencies found in the analyzed areas of the medical facility. The results allow to take appropriate marketing actions to eliminate the observed dysfunctions and implementation of quality management system ${ }^{26}$. The survey on customer satisfaction with the received medical services can also be helpful to the entity performing medical activities in establishing strategies to increase the influence and market share ${ }^{27}$. In order to measure the level of satisfaction of beneficiaries with the quality of dental services we conducted an anonymous survey by questionnaire among 1,000 patients of a network of dental centers in Białystok and its vicinity. With regard to the accepted research problems the author adopted the following research hypothesis: the level of patient satisfaction with the quality of dental services is determined by factors of both tangible and intangible assets associated with the treatment process. Care of dental care facilities over non-medical aspects of service delivery enhances the sense of customer satisfaction from dental practice and strengthens the market position of the facility.

In the studied population, women accounted for $74.4 \%$ and men for $25.6 \%$ of people aged 23 to 67 years. Among the respondents five age groups were isolated: under 29 years of age $(23.3 \%)$, between 30 and 39 years of age (40\%), between 40 and 49 years $(22.2 \%)$ between 50 and 59 years $(89 \%)$ and above 60 years of age $(5.6 \%)$. More than $52.2 \%$ of the patients studied are people between 23 to 35 years of age, of which $78.7 \%$ were women, and only $21.3 \%$ - men. Of the patients participating in the study, $61.1 \%$ had higher education (of which $78.2 \%$ were women), $34.4 \%$ of people secondary education (including 64.5\% - women), and $4.3 \%$ - vocational education. Regarding the issue of payment for benefits earned - in the case of $65.6 \%$ of the patients dental services costs were financed by the National Health Fund (including $71.6 \%$ of women and $47.8 \%$ men), while $34.4 \%$ of those costs of dentist visits was covered from own resources (including $52.2 \%$ of men and $28.4 \%$ women).

The degree of the equipment of the facility with modern instruments and equipment has been very well evaluated by $80 \%$ of patients, with $11.1 \%$ of respondents that could not take a position. From the data obtained it shows that for the majority of respondents $-73.3 \%$ the dentist office hours are convenient, only $4.4 \%$ of the

\footnotetext{
${ }^{26}$ A. Maciąg, I. Sakowska, Rola i prawa pacjenta w obszarze jakości uslug zdrowotnych, „Studia i Materiały Wydziału Zarządzania Uniwersytetu Warszawskiego" 2006, nr 1, s. 53.

${ }^{27} \mathrm{~K}$. Wroński, R. Bocian, Dlaczego zaklady opieki zdrowotnej powinny badać satysfakcje pacjentów z oferowanych przez siebie ushug medycznych?, „Pielęgniarstwo Chirurgiczne i Angiologiczne” 2009, nr 4, s. 128.
} 
respondents expected a more flexible work schedule of the dental office. In this area, none of the respondents did not indicate response bad or very bad.

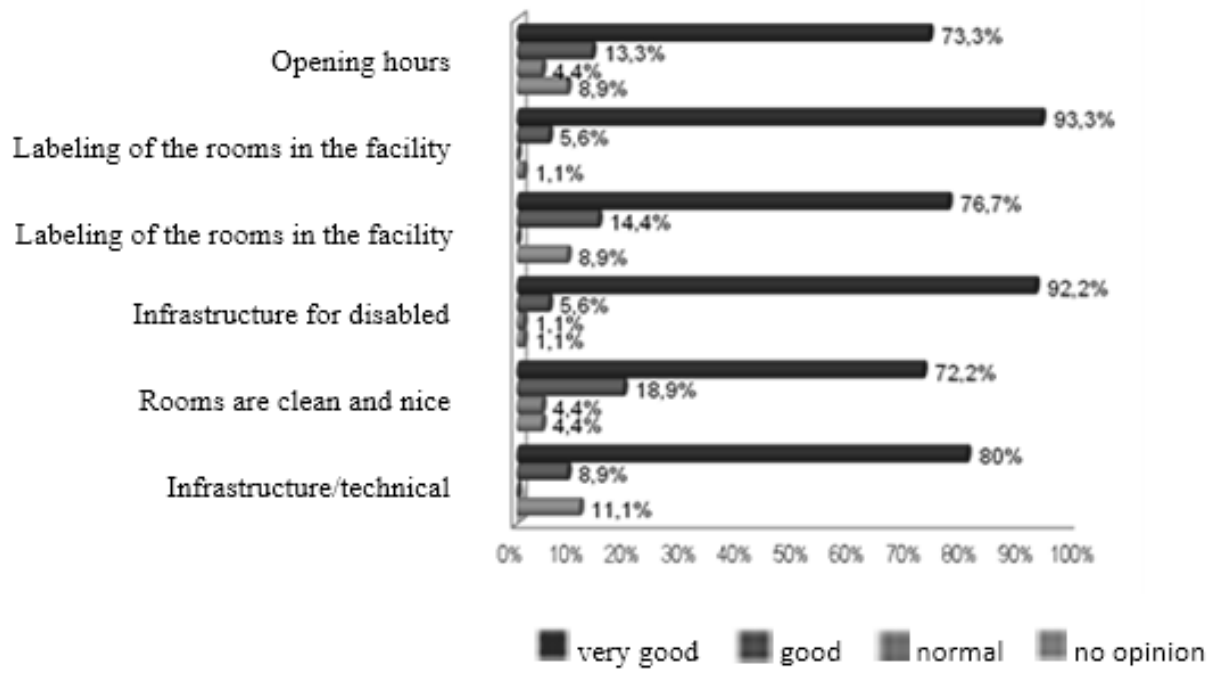

Figure 2. Evaluation of the general conditions of the studied dental offices Source: own study based on research results.

An important factor in patient satisfaction with the service is the atmosphere at the facility, built so by medical staff, and support staff. As a rule, the first contact with the patient have reception attendants and they largely create a positive image of dental office $^{28}$.

The overall organization of the reception desk by the patients surveyed is positive. As many as $84.4 \%$ of respondents highly rated the competencies of staff. As good $(88.9 \%)$ rated the efficiency of the reception staff, but in this category we recorded individuals dissatisfied with the service $(1.1 \%$ - normal, $1.1 \%$ - bad $)$. Similar sentiments accompanied respondents in relation to wait for registration by the employee $-97.8 \%$ of patients rated it as a short waiting time (including $87.8 \%$ - very good, $10 \%$ - good), and $2.2 \%$ - normal. The vast majority of respondents had also no problems in complying with the appointment set. Research shows that patients visiting dental offices meet the kindness, care and kindness of service workers - $100 \%$ of respondents commented positively on this issue (assessment very good - 90\%, and good - 10\%). Instead, greater care on the part of staff requires the clarity of messages and statements formulated to patients.

${ }^{28}$ A. Bukowska-Piestrzyńska, Przyjazne zarzqdzanie personelem pomocniczym gabinetu stomatologicznego. Czesśc I, „, Magazyn Stomatologiczny” 2004, nr 7-8, s. 133. 


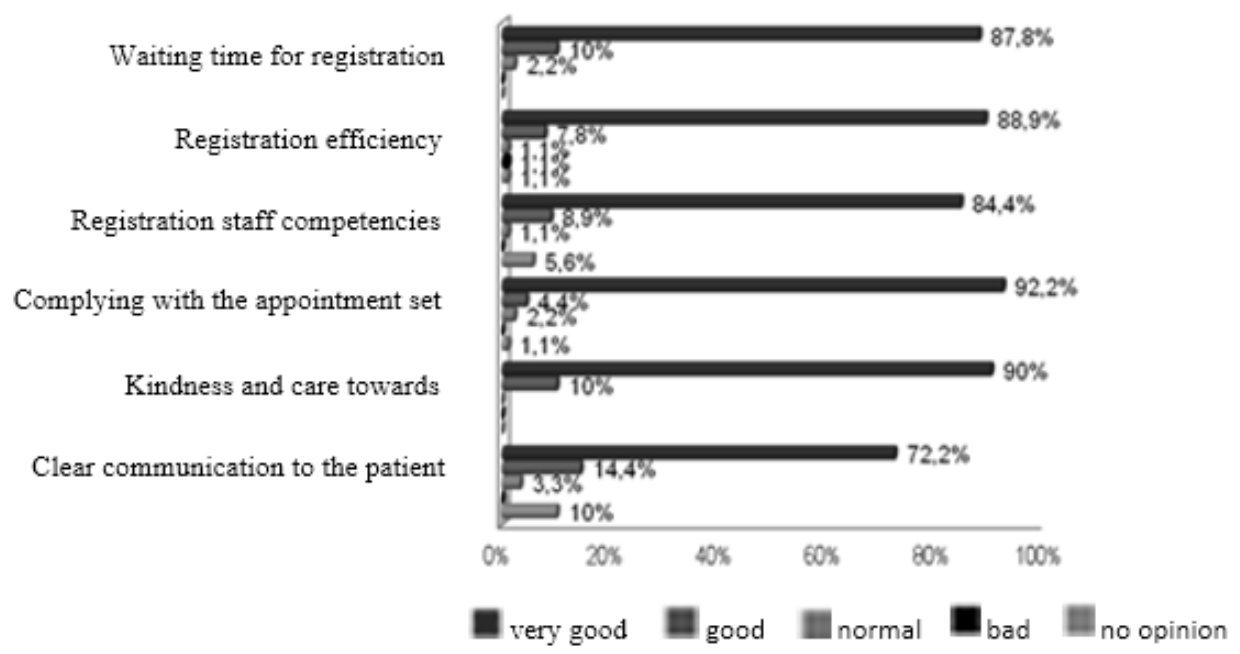

Figure 3. Evaluation of patient service by the staff in surveyed dental institutions Source: own study based on research results.

The vast majority of respondents positively (sum of answers: very good and good - over 90\%) evaluated the non-medical aspects of medical care in the studied dental offices. An analysis of detailed data, however, shows that about $6.7 \%$ of the dentists providing services did not introduced themselves to the patients. Similarly, as many as $6.7 \%$ of respondents were accompanied by the belief that the doctor during the visit did not pay them enough time.

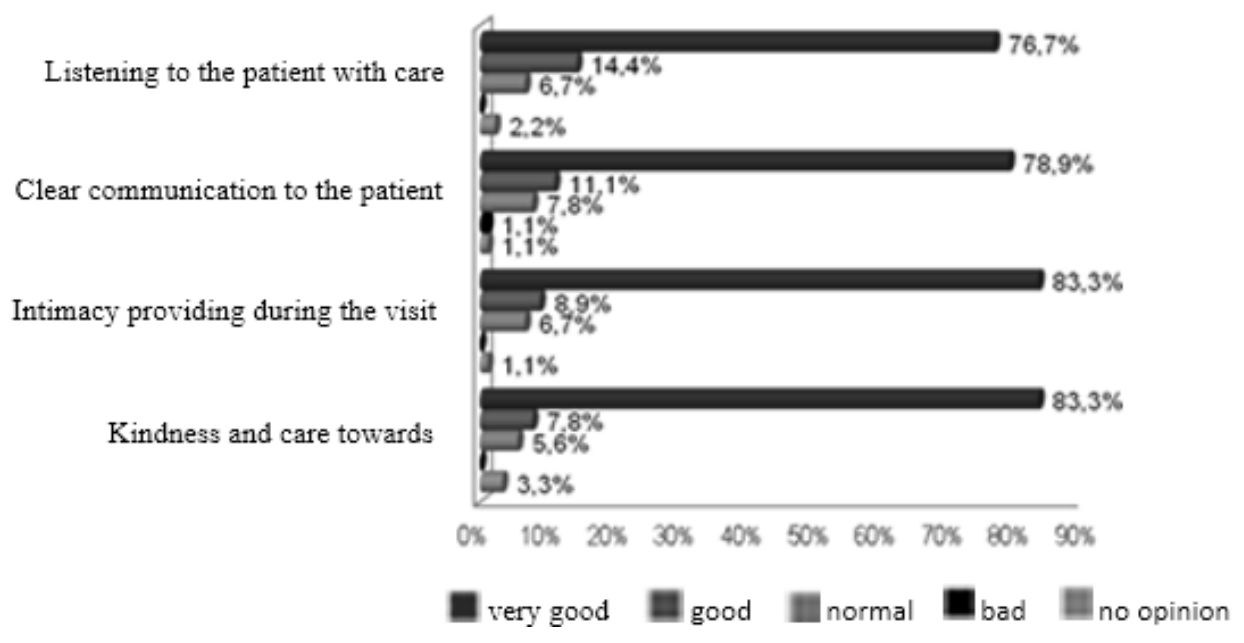

Figure 4. Assessment of the level of medical care in the surveyed dental institutions Source: own study based on research results. 


\section{Summary and conclusions from empirical studies, and proposals for changes in shaping the quality of dental services}

Results of this study indicate a high level of customer satisfaction with the quality of services offered by the facility. Keep in mind that medical service is not only a process of treating the patient, but also a number of perceived additional building blocks for quality of service in the eyes of patients. In case of medical patients, due to lack of their own medical skills, they do not usually have the possibility of substantive assessment of the technical quality of service, and their opinion on the quality of the provision is shaped on the basis of external signs (i.e. environmental services). In the patient's decision about buying a medical service major impact $(70 \%)$ have factors not related to the essence of the service (i.e. additional benefits).

The patient perceives the quality of dental services by assessing his or her own well-being in the dentist's office, or through the prism of intangible factors of services. The satisfaction felt by the patient is greater, if the behavior of personnel of the facility in line with its expectations - hence:

- first impression it is very important of what meets the patient in the office - it is worth paying attention to how the service facility treats a patient at the first contact. The way of customer service says a lot about the company and its brand;

- the patient should be treated kindly, thoughtfully and culturally by the staff. Customer of a dental office expects to meet it with a smile, understanding, compassion and empathy;

- attention to proper flow of information between doctor - patient (use of understandable wording in conversation to the patient).

At the same time studied dental facilities should take further measures to strengthen the material elements of services offered:

- it is necessary to continuously invest in technology - equipment and medical equipment should be modern, and dental materials of high quality;

- they should take care of neat appearance of the medical staff - well are seen corporate uniforms and badges with names. The patient should have in mind the image of a dental assistant as a model of cleanliness, hygiene and professionalism $^{29}$;

- it is important to improve the registration system through proper management of patients visits (patients do not like to change appointments) and proper traffic management in the waiting room (patients do not like delays come into the office, because waiting for a visit in the waiting room is an additional stress factor) ${ }^{30}$;

- you should take care of the psychological comfort of patients waiting for admission by, among others, conversation, advice and information, as well as supplies in a waiting room as appropriately selected newspapers, music, software and movies ${ }^{31}$;

- continuous work on the image of the cabinet (including the Internet, because the patients speak about their feelings of service-related online forums).

\footnotetext{
${ }^{29}$ M. Szumska, Opieka asystentki i higienistki warta miliony, „Asysta Dentystyczna” 2011, nr 1, s. 44-45.

${ }^{30}$ M. Szumska, Oczami pacjentów - cz. I. Wyróżniki stomatologów i ich gabinetów. Badania październik 2009 r., „Twój Przegląd Stomatologiczny” 2010, nr 1-2, s. 95-96.

${ }^{31}$ M. Szumska, Podziat obowiqzków w gabinecie stomatologicznym w zakresie zarzqdzania pacjentami, „Asysta Dentystyczna” 2010, nr 1, s. 40.
} 
To make optimal market decisions, doctor-manager of a medical facility must have adequate knowledge about the needs of patients - not only to meet their needs, but to be able to offer them more than they expect. Appropriate material and organizational action and proper interpersonal communication are the basis for a functioning of a clinic which services receive a good score for patients.

\section{Literature}

Adamowicz M.: Refleksje nad rozwojem i istotą marketingu [w:] Pieniak-Lendzion K., Nowogródzka T.: Współczesny marketing i logistyka-globalne wyzwania, Wydawnictwa UPH, Siedlce 2014.

Bukowska-Piestrzyńska A.: Przyjazne zarządzanie personelem pomocniczym gabinetu stomatologicznego. Cześć I, Magazyn Stomatologiczny” 7-8/2004.

Bukowska-Piestrzyńska A.: Marketing usług zdrowotnych - od budowania wizerunku placówki do zadowolenia klienta, CeDeWu, Warszawa 2007.

Czarnecka K., B. Różański B.: Jakość usług a polityka samorządu lokalnego, Służba Zdrowia 3940/1999.

Czerw A. (red.): Marketing w ochronie zdrowia, Difin, Warszawa 2010.

Czerw A., Religioni U.: Systemy oceny jakości w ochronie zdrowia, Problemy Zarządzania $2 / 2012$.

Dobska M., P. Dobski P.: Marketing usług medycznych, Wydawnictwo INFOR, Warszawa 1999.

Hall R.: Marketing bez tabu, czyli jak to robią najlepsi, Wydawnictwo Edgard, Warszawa 2011.

Iwanicka A.: Satysfakcja i jej rola w aktywności rynkowej nabywcy finalnego, „Zeszyty Naukowe Politechniki Rzeszowskiej” 260/2009.

Jończyk J.: Ocena satysfakcji pacjenta w kontekście jakości opieki zdrowotnej, Prace Naukowe Uniwersytetu Ekonomicznego we Wrocławiu 151/2011

Maciag A., Sakowska I.: Rola i prawa pacjenta w obszarze jakości ustug zdrowotnych, Studia i Materiały Wydziału Zarządzania Uniwersytetu Warszawskiego 1/2006.

Makacewicz S. (i in.): Satysfakcja pacjenta z modelu kompleksowej opieki stomatologicznej, Dental and Medical Problems 43/2006.

Małecka B., J. T. Marcinkowski T.: Satysfakcja pacjenta czynnikiem kształtującym współczesny rynek usług medycznych, Problemy Higieny i Epidemiologii, 88/2007.

Mazurek-Łopacińska K.: Zachowania nabywców i ich konsekwencje marketingowe, PWE, Warszawa 2003.

Nieżurawski L., Pawłowska B., Witkowska J.: Satysfakcja klienta. Strategia - Pomiar Zarządzanie. Koncepcja wewnętrznego urynkowienia współczesnej organizacji, Wydawnictwo Naukowe Uniwersytetu Mikołaja Kopernika, Toruń 2010.

Nowicki P., T. Sikora T.: Czynniki kształtujące satysfakcję klienta oraz korzyści z pomiaru satysfakcji klienta w procesie doskonalenia jakości [w:] Sikora T. (red.) Zarządzanie Jakością Doskonalenie Organizacji, Wydawnictwo Uniwersytetu Ekonomicznego w Krakowie, Kraków 2010.

Opolski K., Dykowska G., Możdżonek M.:Zarządzanie przez jakość w usługach zdrowotnych. Teoria i praktyka, CeDeWu, Warszawa 2010.

Szumska M.: Opieka asystentki i higienistki warta miliony, Asysta Dentystyczna 1/ 2011.

Szumska M., Oczami pacjentów - cz. I. Wyróżniki stomatologów i ich gabinetów. Badania październik 2009 r., Twój Przegląd Stomatologiczny 1-2/2010.

Szumska A.: Podzial obowiqzków $w$ gabinecie stomatologicznym $w$ zakresie zarzq̨ania pacjentami, „Asysta Dentystyczna” 1/2010.

Szymańska J. (i in.), Satysfakcja pacjenta z usług świadczonych w gabinecie stomatologicznym, Zdrowie Publiczne 118/2008. 
Ustawa z dnia 15 kwietnia 2011 r. o działalności leczniczej (Dz. U. z 2013 r. poz. 217, z późn. zm.), art. 2 ust. 1 pkt 5 .

Wereda W.:, Zarządzanie relacjami z klientem (CRM) a postępowanie nabywców na rynku usług, Difin, Warszwa 2009.

Wroński K., R. Bocian R.: Dlaczego zakłady opieki zdrowotnej powinny badać satysfakcje pacjentów z oferowanych przez siebie ustug medycznych?, Pielęgniarstwo Chirurgiczne i Angiologiczne 4/2009.

Zielińska Z. (i in.): Potrzeby i popyt na usługi medyczne, Materiały Konferencyjne, IRWiK, Warszawa 2000 s. 6 [za:] Krot K.: Jakość i marketing usług medycznych, Wolters Kluwer Polska, Warszawa 2008.

\section{Streszczenie}

Świadomość zmiany zasad funkcjonowania opieki zdrowotnej skłania podmioty lecznicze do ciagłego dostosowywania się do oczekiwań świadczeniobiorców oraz doskonalenia jakości oferowanych usług. Nie byłoby to możliwe bez stałego monitorowania poziomu satysfakcji pacjentów i analizowania czynników wpływających na ich zadowolenie. Satysfakcja pacjenta stała się jednym $z$ głównych narzędzi kształtowania jakości $w$ opiece zdrowotnej, a tym samym gwarantem sukcesu organizacji na rynku usług stomatologicznych. Celem niniejszego opracowania jest przedstawienie na poziomie teoretycznym i praktycznym roli satysfakcji konsumenta na rynku usług medycznych na przykładzie rynku usług stomatologicznych. Głównymi metodami zastosowanymi w artykule jest weryfikacja literatury oraz źródeł pierwotnych pozyskanych od badanych placówek, jak również analiza wyników badania ankietowego przeprowadzanego wśród pacjentów pochodzących z Białegostoku i okolic.

Słowa kluczowe: satysfakcja klienta, placówka medyczna, ustugi stomatologiczne, wspótczesny marketing

Informacja o autorach:

dr Wioletta Wereda

Faculty of Economics and Law

University of Natural Sciences and Humanities in Siedlce

email: weredaw@uph.edu.pl

dr Joanna A. Jończyk

Faculty of Management, Bialystok University of Technology

email: j.jonczyk@pb.edu.pl 